Special issue of the SAJHE: 31(2) 2017

\title{
PROBLEMATISING WRITING RETREATS FOR ACADEMIC STAFF IN HIGHER EDUCATION
}

\author{
M. Paxton* \\ Centre for Higher Education and Development \\ University of Cape Town \\ Cape Town, South Africa \\ e-mail: Moragh.Paxton@uct.ac.za
}

\section{J. Garraway*}

Centre for Teaching and Learning

Cape Peninsula University of Technology

Cape Town, South Africa

e-mail: garrawayj@cput.ac.za

\section{Bozalek*}

Teaching and Learning

University of the Western Cape

Cape Town, South Africa

e-mail: vbozalek@gmail.com

${ }^{*}$ Guest editors

Recent student protests have underlined the persistent underfunding of higher education in South Africa with state contributions to university education declining from 49 per cent in 2000 to 40 per cent in 2012. At the same time the post apartheid era has seen student numbers in higher education double. Yet what is seldom mentioned in the media coverage given to the \#FeesMustFall protests is the impact that all this has had on university staff. Staff have had to do more with less. Larger classes, more marking and growing pressure to offer quality teaching has led to a more demanding working environment with less time for research. Yet the pressure to publish has not gone away. Academic staff are still expected to do the scholarly work and to publish it, in fact their jobs may depend on this. The literature indicates that writing retreats offer university teachers space and time away from work and an opportunity to obtain support and feedback in the process of writing for publication (Morss and Murray 2001; Moore 2003; 
Grant 2006; Murray and Newton 2009).

However, these retreats at peaceful and remote venues are an expensive privilege and those of us who organise and facilitate them need to be sure that they add real value. We do need to be monitoring output from our retreats but this is not enough. Publication counts provide only one rather unreliable lens on the effectiveness of writing because writing development is notoriously trick to measure (Witte and Faigley 1983; White 1990; McLeod 1992) and, as Grant (2006) indicates, measurable outcomes from writing retreats are difficult to achieve. For instance, how do we really know when a research article is finally published, what the impact of the writing retreat was? Therefore, in addition to measuring outcomes we need more qualitative research and evaluation which will enable a rethinking of our pedagogies and a sharing of ideas. The literature on writing retreats has tended to concentrate on the importance of retreating to write and on the different models for writing retreats (Murray 2010). It has seldom, however, focused critically on the complexities of teaching and learning to write.

This special issue sponsored by a Department of Higher Education National Collaborative Teaching Development Grant has encouraged contributors to rethink and re-imagine the pedagogies for writers' retreats with more in depth and theoretically framed understandings of how particular writing pedagogies work and why they are effective. The special edition offers an exciting diversity of approaches to learning and teaching on writing retreats across a wide spectrum. Some articles in this volume focus on philosophies for more fruitful writing experiences such as mindfulness, free writing and slow pedagogy, others consider writing retreats as communities of practice, open spaces and a third space. Then at the other end of the spectrum there are articles on knowledge building and genre based research.

\section{ACKNOWLEDGEMENTS}

This special edition on writing retreats in South Africa and a retreat where some of the articles were written was supported by funding from the Department of Higher Education National Collaborative Teaching Development Grant: The improvement of teaching and learning in South African universities through researching and evaluating TDG projects in the First Year Experience (FYE) initiatives, Tutorials, Mentoring and Writing Retreats.

\section{REFERENCES}

Grant, B. 2006. Writing in the company of other women: Exceeding the boundaries. Studies in Higher Education 31(4): 483-495.

McLeod, S. 1992. Evaluating writing programs: Paradigms, problems, possibilities. Journal of Advanced Composition 12(2): 373-382. 
Moore, S. 2003. Writers retreats for academics: Exploring and increasing the motivation to write. Journal of Further and Higher Education 27(3): 333-342.

Morss, K. and R. Murray. 2001. Researching academic writing within a structural program: Insights and outcomes. Studies in Higher Education 26(1): 35-52.

Murray, R. 2010. Becoming rhetorical. In Publishing pedagogies for the doctorate and beyond, ed. C. Aitchison, B. Kamler and A. Lee, 101-116. London and New York: Routledge Taylor and Francis Group.

Murray, R. and M. Newton. 2009. Writing Retreat as Structured Intervention: Margin or Mainstream? Higher Education Research Development 28(5): 541-553.

White, E. M. 1990. Language and reality in writing assessment. College Composition and Communication 41: 187-200.

Witte, S. P. and L. Faigley. 1983. Evaluating college writing programmes. Carbondale and Edwardsville: Southern Illinois University Press. 